\title{
Article/Artigo
}

\section{Species distribution and in vitro fluconazole susceptibility of clinical Candida isolates in a Brazilian tertiary-care hospital over a 3-year period}

\author{
Distribuição de espécies e suscetibilidade in vitro ao fluconazol de isolados clínicos de Candida \\ em um hospital terciário brasileiro num período de três anos
}

\begin{abstract}
Márcia Cristina Furlaneto ${ }^{1}$, Juliana Frasnelli $\operatorname{Rota}^{1}$, Regina Mariuza Borsato Quesada ${ }^{2}$, Luciana Furlaneto-Maia ${ }^{3}$, Renne Rodrigues ${ }^{2}$, Silas Oda $^{2}$, Marcelo Tempesta de Oliveira ${ }^{1}$, Rosana Serpa ${ }^{1}$ and Emanuele Júlio Galvão de França ${ }^{1}$
\end{abstract}

\begin{abstract}
Introduction: In this study, we aimed at identifying Candida isolates obtained from blood, urine, tracheal secretion, and nail/skin lesions from cases attended at the Hospital Universitário de Londrina over a 3-year period and at evaluating fluconazole susceptibilities of the isolates. Methods: Candida isolates were identified by polymerase chain reaction (PCR) using speciesspecific forward primers. The in vitro fluconazole susceptibility test was performed according to EUCAST-AFST reference procedure. Results: Isolates were obtained from urine (53.4\%), blood cultures (19.2\%), tracheal secretion (17.8\%), and nail/skin lesions (9.6\%). When urine samples were considered, prevalence was similar in women (45.5\%) and in men (54.5\%) and was high in the age group $\geq 61$ years than that in younger ones. For blood samples, prevalence was high in neonates $(35 \%)$ and advanced ages $(22.5 \%)$. For nail and skin samples, prevalence was higher in women $(71.4 \%)$ than in men $(28.6 \%)$. Candida albicans was the most frequently isolated in the hospital, but Candida species other than C. albicans accounted for $64 \%$ of isolates, including predominantly Candida tropicalis (33.2\%) and Candida parapsilosis (19.2\%). The trend for non-albicans Candida as the predominant species was noted from all clinical specimens, except from urine samples. All Candida isolates were considered susceptible in vitro to fluconazole with the exception of isolates belonging to the intrinsically less-susceptible species C. glabrata. Conclusions: Non-albicans Candida species were more frequently isolated in the hospital. Fluconazole resistance was a rare finding in our study.
\end{abstract}

Keywords: Candidiasis. Candida spp. Anatomic sites.

\section{RESUMO}

Introdução: Neste estudo objetivamos a identificação de isolados de Candida obtidos de sangue, urina, secreção traqueal e de lesões de unha/pele, de casos atendidos no Hospital Universitário de Londrina num período de três anos. Avaliamos também a suscetibilidade dos isolados ao fluconazol. Métodos: Os isolados de Candida foram identificados pela reação em cadeia da polimerase (RCP) usando oligonucleotídeos iniciadores espécie-específicos. O teste de suscetibilidade in vitro ao fluconazol foi realizado segundo o procedimento de referência EUCAST-AFST. Resultados: Isolados foram obtidos de urina (53,4\%), sangue (19,2\%), secreção traqueal $(17,8 \%)$ e lesões de unha/pele (9,6\%). Considerando as amostras de urina, a prevalência foi similar em mulheres $(45,5 \%)$ e em homens $(54,5 \%)$ e foi alta no grupo de idade $\geq 61$ anos do que em grupos mais jovens. Para amostras de sangue a prevalência foi alta em neonatos (35\%) e idades avançadas (22,5\%). Para amostras de unha e pele a prevalência foi maior em mulheres $(71,4 \%)$ do que em homens $(28,6 \%)$. Candida albicans foi a mais frequentemente isolada no hospital, mas outras espécies de Candida corresponderam a 64\% dos isolados, incluindo predominantemente Candida tropicalis (33,2\%) e Candida parapsilosis (19,2\%). A tendência de Candida não-albicans como espécie predominante foi observada para todas as amostras clínicas, exceto para amostras de urina. Todos isolados de Candida foram considerados suscetíveis, in vitro, ao fluconazol com exceção dos isolados pertencentes às espécies intrinsecamente menos suscetíveis C.glabrata. Conclusões: Espécies de Candida não-albicans foram mais frequentemente isoladas no hospital. Resistência ao fluconazol foi rara no nosso estudo.

Palavras-chaves: Candidiasis. Candida spp. Sítios anatômicos.

1. Departamento de Microbiologia, Centro de Ciências Biológicas, Universidade Estadual de Londrina, Londrina, PR. 2. Centro de Ciências da Saúde, Universidade Estadual de Londrina, Londrina, PR. 3. Departamento de Ensino, Universidade Tecnológica Federal do Paraná, Londrina, PR.

Address to: Dra. Márcia Cristina Furlaneto. Dept ${ }^{\circ}$ Microbiologia/CCB/UEL. Caixa Postal 6.001, 86051-990 Londrina, PR, Brasil.

Phone: 5543 3371-5736

email: furlaneto@uel.br

Received in 23/02/2011

Accepted in 11/05/2011

\section{INTRODUCTION}

Although ubiquitous in nature, Candida species can cause various infections primarily in hospitalized patients. With the evolution of intensive care medicine, it has become increasingly evident that critically ill patients represent a patient population susceptible to candidal infections. The increased susceptibility of these patients is largely due to the use of invasive devices, impaired immune mechanisms due to severe underlying illness, and widespread use of antibiotics ${ }^{1,2}$.

In Brazil, studies regarding the epidemiology of Candida infections in tertiary-care hospitals are still limited to few regions, with the majority being related to bloodstream infection ${ }^{1,3-13}$.

Although Candida albicans remains the main individual etiologic agent of candidemia, an increase in the number of cases caused by non-albicans species has been reported, including in Brazilian medical centers ${ }^{1,3-4,7,9-10}$. The most common nonalbicans Candida species causing bloodstream infections are Candida parapsilosis and Candida tropicalis ${ }^{14}$.

Fluconazole is a systemic antifungal drug effective against most of the Candida species, although different degrees of susceptibility among species have been described; for example, Candida krusei has intrinsic resistance, and Candida glabrata shows less susceptibility than other Candida species ${ }^{15}$. Furthermore, the emergence of fluconazole resistance has been reported in C. albicans, C. tropicalis, and C. parapsilosis ${ }^{16-20}$, including that observed in a Brazilian tertiary-care hospital ${ }^{13,21-22}$ that justifies the correct species identification and evaluation of their susceptibilities.

In this study, we analyzed for the first time the species distribution and fluconazole susceptibility of Candida isolates in the Hospital Universitário de Londrina, Parana State, Brazil. 


\section{METHODS}

\section{Candida isolates and cultures}

We evaluated Candida sp. isolates obtained from patients admitted at the Hospital Universitário de Londrina (HU), a general tertiary-care hospital with 333 beds, including 43 intensive care unit (ICU) beds, in the southern Brazil from January 2005 to December 2007. The following data were recorded: sex, age, and patient location at the time of Candida detection.

Surveillance fungal cultures were obtained from several specimens during the trial. Cultures included in this study were those of the urine, blood, tracheal secretion, and superficial mycoses (nail/skin). For the urine specimens, Candida isolates were selected from significant candiduria $\left(\geq 10^{4} \mathrm{CFU} / \mathrm{mL}\right)$. The tracheal secretion isolates were colonization. The specimens were cultured using standard mycological procedures. Samples were inoculated on Sabouraud Dextrose Agar supplemented with chloramphenicol $(100 \mu \mathrm{g} / \mathrm{ml})$. The plates were incubated at $28^{\circ} \mathrm{C}$ for $48 \mathrm{~h}$. All the collected isolates were stored in yeast peptone dextrose (YPD) medium with $25 \%$ glycerol at $-70^{\circ} \mathrm{C}$ and were deposited at the Candida culture collection of the Fungal Genetics Laboratory, Universidade Estadual de Londrina-Brazil.

\section{Species identification}

CHROMagar ${ }^{\circledR}$ Candida plates (CHROMagar Candida; CHROMagar ${ }^{\circledR}$, France) were used for presumptive identification of Candida species. Definitive identification of all clinical isolates assayed in this work belonging to the genus Candida was performed by using a PCR-based method. PCR identification was carried out using species-specific forward primers (ITS1 and ITS2) corresponding to intergenic spacer regions and ITS4 as universal reverse primer located at the $26 \mathrm{~S}$ rDNA as follows: CA (Candida albicans, 5'-TCA ACT TGT CAC ACC AGA TTA TT-3'), CT (Candida tropicalis, 5' -AAG AAT TTA ACG TGG AAA CTT A-3'), CGL (Candida glabrata, 5'-CAC GAC TCG ACA CTT TCT AAT T-3'), CP (Candida parapsilosis, 5'-GGC GGA GTA TAA ACT AAT GGA TAG-3'), and CK (Candida krusei, 5'-GAT TTA GTA CTA CAC TGC GTG A-3') ${ }^{23}$. ITS4 ( $5^{\prime}$-TCC TCC GCT TAT TGA TAT GC- $3^{\prime}$ ) was used as described previously ${ }^{24}$. The identity of $C$. parapsilosis isolates was confirmed by the employment of primers for URA3 gene (orotidine-5' -phosphate decarboxylase) as described previously ${ }^{25}$.

PCR was carried out using genomic DNA obtained as described by Furlaneto-Maia et al. ${ }^{26}$. For the optimum PCR conditions, a reaction volume of $20 \mu \mathrm{L}$ contained $0.8 \mu \mathrm{L}(2.5 \mu \mathrm{M})$ of each deoxynucleoside triphosphate, $0.6 \mu \mathrm{L}(50 \mathrm{mM})$ magnesium chloride, $0.5 \mu \mathrm{L}(20 \mathrm{pmol} / \mu \mathrm{L})$ of each primer, $10 \mathrm{x}$ Taq buffer and $1 \mathrm{U}$ of Taq polymerase (Invitrogen), and $21(5 \mathrm{ng} / \mu \mathrm{L})$ DNA template. Negative controls were performed with sterile deionised water in place of the template DNA. Reaction mixtures were subjected to an initial denaturing cycle of $5 \mathrm{~min}$ at $96^{\circ} \mathrm{C}$, followed by 34 cycles of $94^{\circ} \mathrm{C}$ for $1 \mathrm{~min}$ (denaturation), $60^{\circ} \mathrm{C}$ for $1 \mathrm{~min}$ (annealing), and $72^{\circ} \mathrm{C}$ for $1 \mathrm{~min}$ (elongation). The sizes of amplified DNA fragments were identified by comparison with molecular size marker DNA (100 bp DNA ladder). The identification of C. dubliniensis was based on phenotypic characteristics ${ }^{27}$.

\section{In vitro antifungal susceptibility testing}

A total of 201 samples of Candida spp. were tested. The in vitro antifungal susceptibility test was performed according to the EUCAST-AFST reference procedure (EDef 7.1) (28 $^{28}$ using fluconazole (Sigma-Aldrich) as antifungal drug. Fluconazole powder was dissolved in sterile distilled water, in a stock solution at $6400 \mathrm{ug} / \mathrm{mL}$, and stored at $-20^{\circ} \mathrm{C}$ overnight.

The yeast isolates were grown on Sabouraud dextrose agar for $24 \mathrm{~h}$ at $37^{\circ} \mathrm{C}$. Suspensions were prepared in sterile saline $(0.9 \%)$, adjusted to $1-5 \times 10^{5}$ cells $/ \mathrm{mL}$.

Serial dilutions of fluconazole were performed in RPMI-1640 medium, supplemented with glucose $2 \%(\mathrm{w} / \mathrm{v})$ and buffered with $0.165 \mathrm{M}$ morpholinepropanesulfonic acid (MOPS-Sigma-Aldrich). The final ranges of the drug dilutions tested were 0.125 to $64 \mathrm{mg} / \mathrm{L}$.

Flat-bottom microdilution plates containing $100 \mathrm{uL}$ of the twofold serial dilutions of fluconazole were inoculated with $100 \mathrm{uL}$ of the inocula. The final concentration of cells was 0.5 to $2.5 \times 10^{5} \mathrm{cells} / \mathrm{mL}$. The microdilution plates were incubated at $37^{\circ} \mathrm{C}$ for $24 \mathrm{~h}$. Each sample was tested in triplicate. Minimal inhibitory concentration (MIC) endpoints were determined spectrophotometrically at $590 \mathrm{~nm}$. $\mathrm{MIC}_{90}$ was defined as the concentration capable of reducing the growth of $90 \%$ of the total population. C. parapsilosis ATCC 22019 and C. krusei ATCC 6258 standard strains were used as quality controls of the tests ${ }^{28}$. Interpretative breakpoints proposed by EUCAST for fluconazole (susceptible $\leq 2 \mathrm{mg} / \mathrm{L}$ and resistant $\geq 8 \mathrm{mg} / \mathrm{L}$ ) were used $^{28}$.

\section{Ethical considerations}

This study was approved by the Ethics Committee of Hospital Universitário da Universidade Estadual de Londrina-PR.

\section{RESULTS}

\section{Isolates identification}

In this study, a total of 208 Candida isolates were obtained from individual patients, including: C. albicans $(\mathrm{n}=75)$, C. tropicalis $(\mathrm{n}=69)$, C. krusei $(\mathrm{n}=4)$, and Candida sp. $(\mathrm{n}=59)$ in CHROMagar® Candidayeast differential medium. In our experiments, C. albicans colonies appeared green, C. krusei appeared dry and light pink with a whitish border, and $C$. tropicalis appeared dark blue to metallic blue. Further identification carried out using PCR method revealed high accuracy in specificity. The PCR amplification of rDNAs from the three Candida species, C. albicans, C. tropicalis, and C. krusei, resulted in amplification of a single DNA fragment of the expected size (data not shown).

The employment of species-specific primer corresponding to the intergenic spacer region (ITS) sequence from C. parapsilosis (CP) e C. glabrata (CGL) allowed the identification of C. parapsilosis complex $(\mathrm{n}=40)$ and C. glabrata $(\mathrm{n}=17)$ isolates incompletely identified by CHROMagar® Candida characteristics. Two isolates remained not identified at the species level. The identity of C. parapsilosis (formerly C. parapsilosis group I) isolates was confirmed by the employment of primers corresponding to URA3 gene as previously described ${ }^{25}$. None of the isolates were C. orthopsilosis (formerly C. parapsilosis group II) or C. metapsilosis (formerly C. parapsilosis group III).

In this study, we have employed the tobacco agar medium for the differentiation of $C$. dubliniensis from C. albicans ${ }^{27}$. On this medium at $28^{\circ} \mathrm{C}$, only one isolate produced yellowish-brown colonies with hyphal fringes ( $C$. dubliniensis), whereas the remaining isolates formed smooth, white- to cream-colored colonies (C. albicans). 


\section{Sex- and age-specific distribution of Candida isolates}

As shown in Table 1, the majority (86\%) of isolates from urine specimen were obtained from patients at ICU. Prevalence was similar in women $(45.5 \%)$ and in men $(54.5 \%)$. When urine samples were considered, prevalence was high in the age group $\geq 61$ years than that in younger ones.

Considering bloodstream infection, $90 \%$ of the patients were from intensive care units. For blood samples, prevalence was high in neonates (35\%) followed by advanced ages (22.5\%).

Isolates from tracheal secretion and superficial (nail and skin) lesions represented $17.8 \%$ and $9.6 \%$ of the isolates obtained in this 3 -year survey, respectively. Concerning sex, for tracheal secretion samples, prevalence was higher in men $(66 \%)$. On the other hand for nail and skin samples, it was higher in women (71.4\%) than in men (28.6\%). For both body-site samples, prevalence was significantly higher in the age group $\geq 61$ years than that in younger ones (Table 1).

\section{Species distribution}

In a total of 208 Candida cultures, C. albicans represented 36\%, while non-albicans Candida accounted for the majority (64\%) of these isolates obtained from distinct clinical samples. Table 2 shows the species distribution of Candida isolates with regard to clinical samples. Urine was the most common source of the Candida, accounting for $53.4 \%$ of the total isolates, with the following colony counting: $10^{4} \mathrm{CFU} / \mathrm{mL}$ (20.7\%), $10^{5}-10^{6} \mathrm{CFU} / \mathrm{mL}$ (37.7\%), and $10^{7}$ $\mathrm{CFU} / \mathrm{mL}$ (20.7\%). Most C. albicans strains were isolated from urine samples (45\%). Distribution of identified non-albicans species from urine was: C. tropicalis - 36.1\%; C. glabrata - 12.6\%; C. parapsilosis $-3.6 \%$; C. krusei - 1.8\%; and C. dubliniensis - $0.9 \%$, as shown in Table 2. In this study, we found a low rate of C. dubliniensis isolates among a total of 75 isolates previously identified as C. albicans. Of the isolates obtained from blood cultures, $75 \%$ were non-albicans Candida species, the most common being $C$. tropicalis, followed by C. parapsilosis (Table 2). Prevalence of non-albicans Candida species was also observed from nail/skin infection specimens, the most common being C. parapsilosis (45\%) and C. tropicalis (35\%). Most C. parapsilosis strains were isolated from tracheal secretion samples $(46 \%)$.

\section{Susceptibility tests}

Susceptibility tests for fluconazole were performed on 205 isolates of Candida species. Table 3 shows the MICs at which 50\% (MIC50) and 90\% (MIC90) of the isolates tested were inhibited for fluconazole. The majority of Candida isolates were considered susceptible to fluconazole (MIC of $\leq 2 \mathrm{mg} / \mathrm{L}$ ), with the exception of C. glabrata isolates that are intrinsically less susceptible to fluconazole (Table 3). MIC readings for quality control strains (ATCC 90028 and ATCC 22019) were within the limits described in the (EDef 7.1)28.

TABLE 1 - Characteristics of patients with candidiasis according to specimen type of yeast isolation.

\begin{tabular}{|c|c|c|c|c|}
\hline \multirow[b]{2}{*}{ Characteristics } & \multicolumn{4}{|c|}{ Specimen sample ${ }^{a}$} \\
\hline & $\begin{array}{c}\text { urine } \\
(\mathrm{n}=111)\end{array}$ & $\begin{array}{l}\text { blood } \\
(n=40)\end{array}$ & $\begin{array}{l}\text { tracheal secretion } \\
(\mathrm{n}=37)\end{array}$ & $\begin{array}{c}\text { nail/skin lesions } \\
(\mathrm{n}=20)\end{array}$ \\
\hline Gender $(M / F)^{b}$ & $(54.5 / 45.5)$ & $(40.0 / 25.0)$ & $(66.0 / 34.0)$ & $(28.6 / 71.4)$ \\
\hline \multirow{5}{*}{$\operatorname{Age}^{b, c}$} & $\leq 1-18(10.0)$ & Neonate (35.0) & $\leq 1-18(2.7)$ & $38-61(43.0)$ \\
\hline & $19-35(20.5)$ & $\leq 1-18(10.0)$ & $27-60(24.3)$ & $\geq 61(57.0)$ \\
\hline & $36-60(25.5)$ & $19-35(15.0)$ & $\geq 61(73.0)$ & \\
\hline & $\geq 61(44.0)$ & $36-60(17.5)$ & & \\
\hline & & $\geq 61(22.5)$ & & \\
\hline \multirow{4}{*}{ Patient location $b$} & Adult ICU (86.0) & Adult ICU (50.0) & & \\
\hline & Hospitalized (14.0) & Neonate ICU (35.0) & ND & ND \\
\hline & & Pediatrics ICU (5.0) & & \\
\hline & & Others (10.0) & & \\
\hline
\end{tabular}

TABLE 2 - Distribution of Candida species and the clinical samples.

\begin{tabular}{|c|c|c|c|c|c|c|c|c|}
\hline \multirow[b]{2}{*}{ Specimentype } & \multicolumn{6}{|c|}{ Candida species ${ }^{\mathrm{a}}$} & \multirow[b]{2}{*}{ Candida sp. } & \multirow[b]{2}{*}{ Total } \\
\hline & albicans & tropicalis & parapsilosis & glabrata & krusei & dubliniensis & & \\
\hline Urine & $50(45.0)$ & $40(36.1)$ & $4(3.6)$ & $14(12.6)$ & $2(1.8)$ & $1(0.9)$ & - & 111 \\
\hline Blood & $10(25.0)$ & $14(35.0)$ & $10(25.0)$ & $2(5.0)$ & $2(5.0)$ & - & $2(5.0)$ & 40 \\
\hline Tracheal secretion & $12(32.4)$ & $8(21.6)$ & $17(46.0)$ & - & - & - & - & 37 \\
\hline Nail/skin lesions & $3(15.0)$ & $7(35.0)$ & $9(45.0)$ & $1(5.0)$ & - & - & - & 20 \\
\hline Total & $75(36.0)$ & $69(33.2)$ & $40(19.2)$ & $17(8.2)$ & $4(1.9)$ & $1(0.5)$ & $2(1.0)$ & 208 \\
\hline
\end{tabular}


TABLE 3 - In vitro susceptibilities to fluconazole of Candida species isolates

\begin{tabular}{|c|c|c|c|c|}
\hline \multirow{2}{*}{$\begin{array}{l}\text { Candida species } \\
\text { (Number isolates) }\end{array}$} & \multicolumn{3}{|c|}{ MIC values $(\mathrm{mg} / \mathrm{L})$} & \multirow{2}{*}{$\begin{array}{c}\text { resistant }(\%)^{\mathrm{a}} \\
(\mathrm{N} \text { of isolates) }\end{array}$} \\
\hline & range & $50 \%$ & $90 \%$ & \\
\hline albicans (75) & $0.125-8.0$ & 0.5 & 2.0 & $1.3(1)$ \\
\hline tropicalis (69) & $0.125-32$ & 1.0 & 2.0 & $7.2(5)$ \\
\hline parapsilosis (40) & $0.125-16$ & 1.0 & 2.0 & $2.5(1)$ \\
\hline glabrata (17) & $0.25-32$ & 8.0 & 16.0 & $64.7(11)$ \\
\hline
\end{tabular}

$\mathbf{a}_{\text {resistance breakpoints MIC of }}{ }^{3} 8 \mathrm{mg} / \mathrm{L}$, MIC: minimal inhibitory concentration.

\section{DISCUSSION}

Infection represents a frequent complication among patients admitted to tertiary hospitals. In particular, the incidence of candidiasis has been increasing during the past years. The largest multicentric study conducted in Latin America reveals a large burden of candidemia in Brazilian tertiary-care hospitals ${ }^{1}$.

In this study, the isolate identification in species level by CHROMagar ${ }^{\circledR}$ Candida medium was in agreement to what was found in molecular identification. The PCR approach for species identification that was employed in this study is a reliable and sensitive method for the diagnosis of the most commonly encountered clinical-relevant Candida species. Furthermore, the employment of phenotypic method based on differential growth on tobacco $\operatorname{agar}^{27}$ allowed the identification of one C. dubliniensis isolate (from urine sample). Candida dubliniensis is a newly emerging opportunistic pathogen that shares many phenotypic similarities with C. albicans. These similarities pose problems in the identification of isolates and have previously led to misidentification of these species ${ }^{29}$.

The frequency of non-albicans species from distinct clinical specimens observed here was greater than C. albicans, which is consistent with the results of previous studies in Brazilian tertiary hospitals ${ }^{21,30}$. C. tropicalis was the most frequent species isolated from candidemia (35\%), which frequency was higher than that observed in the Brazilian multicenter study (16\% to $29 \%)^{1}$. The second-most frequent species were $C$. albicans and C. parapsilosis. These data confirm the increasing importance of non-albicans species as agents of fungemia in Brazil. Besides, the low frequency of C. glabrata and C. krusei is in agreement with a previous report that consolidates the concept that candidemia due to these species is rare in Brazil ${ }^{1}$.

An increase of candiduria among hospitalized patients has been reported ${ }^{31-34}$. Although the significance of Candida isolated from urine of patients is still unclear (reviewed in Kauffman ${ }^{35}$ ), the overall mortality associated with ICU candiduria can reach $50 \%{ }^{35}$. In this study, identification of yeasts obtained from urine revealed C. albicans to be the most common species, followed by $C$. tropicalis and much less commonly by other species. Studies conducted in Brazilian medical centers have also shown increased rates of isolation of C. tropicalis from urine $\mathrm{e}^{30,34,37-38}$.

Candida parapsilosis was the species most often isolated from superficial mycoses (nail and skin), followed by C. tropicalis. This is in agreement with other studies that identified C. parapsilosis as the prevalent species in the processes of onychomycosis ${ }^{39-40}$. C. parapsilosis is a common inhabitant of normal skin, and this presumably serves as a reservoir of infection for the nails. Recently, we showed the capability of C. parapsilosis cells to adhere and grow as biofilm on human nail surfaces ${ }^{41}$.
Candida parapsilosis was also prevalent in tracheal secretion specimens, followed by C. albicans. In a multicenter study of immunocompetent patients receiving mechanical ventilation performed in France, Azoulay found that $C$. albicans was the most common species and that the Candida colonization of the respiratory tract may predispose to bacterial ventilator-associated pneumonia ${ }^{42}$.

In the present study, most of the isolates were susceptible to fluconazole. As expected, high resistance rate (64.7\%) was observed in C. glabrata, which is an intrinsically less susceptible species. This resistance rate was similar to that observed by Bruder-Nascimento et al. ${ }^{21}$ who also evaluated the resistance of Candida isolates obtained from distinct clinical specimens in a Brazilian tertiary hospital.

Although much has been reported regarding the epidemiology of Candida infections, the present work is the first report about the distribution of Candida species in invasive and non-invasive candidiasis in our hospital. These data suggest the need for continuous surveillance of candidiasis and antifungal susceptibility trends to adopt treatment strategies applicable to particular healthcare institutions.

\section{CONFLICT OF INTEREST}

The authors declare that there is no conflict of interest.

\section{FINANCIAL SUPPORT}

Pró-Reitoria de Pesquisa e Pós-Graduação of Universidade Estadual de Londrina. Departamento de Ciência e Tecnologia of Secretaria de Ciência e Tecnologia e Insumos Estratégicos of Ministério da Saúde. RS and MTO are fellowship holders of Coordenação de Aperfeiçoamento de Pessoal de Nivel Superior (CAPES). EJGF is fellowship holder of Conselho Nacional de Desenvolvimento Científico e Tecnológico (CNPq). MCF is fellowship holder of Fundação Araucária SETI, Paraná Governament, Brazil.

\section{REFERENCES}

1. Colombo AL, Nucci M, Park BJ, Nouér SA, Arthington-Skaggs B, Matta DA, et al. Epidemiology of candidemia in Brazil: a nationwide sentinel surveillance of candidemia in eleven medical centres. J Clin Microbiol 2006; 44:2816-2823.

2. Magill SS, Swoboda SM, Johnson EA, Merz WG, Pelz RK, Lipsett PA, et al. The association between anatomic site of candida colonization, invasive candidiasis, and mortality in critically ill surgical patients. Diag Microbiol Infect Dis 2006; 55: 293-301.

3. Antunes AGV, Pasqualotto AC, Diaz MC, dAzevedo PA, Severo LC. Candidemia in a Brazilian tertiary care hospital: species distribution and antifungal susceptibility. Rev Inst Med Trop São Paulo 2004; 46: 239-241.

4. Aquino VR, Lunardi LW, Goldani LZ, Barth AL. Prevalence, susceptibility profile for fluconazole and risk factors for candidemia in a tertiary care hospital in southern Brazil. Braz J Infect Dis 2005; 9: 411-418.

5. Medrano DJA, Brilhante RSN, Cordeiro RA, Rocha MFG, Rabenhorst SHB, Sidrim JJC. Candidemia in a Brazilian hospital: the importance of Candida parapsilosis. Rev Inst Med Trop São Paulo 2006; 48: 17-20.

6. Matta DA, Almeida LP, Machado AM, Azevedo AC, Kusano EJU, Travassos NF et al. Antifungal susceptibility of 1000 Candida bloodstream isolates to 5 antifungal drugs: results of a multicenter study conducted in São Paulo, Brazil, 1995-2003. Dig Microbiol Infect Dis 2007; 57: 399-404.

7. Colombo AL, Guimarães T, Silva LRBF, Monfardini LPA, Cunha AKB, Rady P, et al. Prospective observational study of candidemia in São Paulo, Brazil: incidence rate, epidemiology, and predictors of mortality. Infect Control Hosp Epidemiol 2007; 28: 570-576. 
8. Passos XS, Costa CR, Araújo CR, Nascimento ES, Souza LKH, Fernandes OFL, et al. Species distribution and antifungal susceptibility patterns of Candida spp. Bloodstream isolates from a Brazilian tertiary care hospital. Mycopathologia 2007; 163: 145-151.

9. Chang MR, Correia FP, Costa LC, Xavier PCN, Palhares DB, Taira DL, et al. Candida bloodstream infection: data from a teaching hospital in Mato Grosso do Sul, Brazil. Rev Inst Med Trop 2008; 50: 265-268.

10. França JCB, Ribeiro CEL, Queiroz-Telles F. Candidemia in a Brazilian tertiary care hospital: incidence, frequency of different species, risk factors and antifungal susceptibility. Rev Soc Bras Med Trop 2008; 41: 23-28.

11. Hinrichsen SL, Falcão E, Vilella TAS, Colombo AL, Nucci M, Moura L, et al. Candidemia in a tertiary hospital in northeastern Brazil. Rev Soc Bras Med Trop 2008; 41: 394-398.

12. Parahym AMRD, De Mello LRB, De Morais VLL, Neves RP. Candidiasis in pediatric patients with cancer interned in a university hospital. Braz J Microbiol 2009; 40: 321-324.

13. Pereira GH, Mulles PR, Szeszs MW, Levin AS, Melhem MSC. Five-year evaluation of bloodstream yeast infections in a tertiary hospital: the predominance of non-C. albicans Candida species. Med Mycol 2010; 48: 839-842.

14. Nucci M, Queiroz-Telles F, Tobon AM, Restrep A, Colombo AL. Epidemiology of opportunistic fungal infections in Latin America. Clin Infect Dis 2010; 51: 561-570.

15. Pfaller MA, Diekema DJ, Rinaldi MG, Barnes R, Hu B, Veselov AV, et al. Results from the ARTEMIS DISK Global Antifungal Surveillance Study: a 6.5 year analysis of susceptibilities of Candida and other yeast species to fluconazole and voriconazole by standardized disk diffusion testing. J Clin Microbiol 2005; 43: 5848-5859.

16. Yang YL, Ho YA, Cheng HH, Ho M, Lo HJ. Susceptibilities of Candida species to amphotericin B and fluconazole: the emergence of fluconazole resístanse in Candida tropicalis. Infect Control Hosp Epidemiol 2004; 25: 60-64.

17. Hajjeh RA, Sofair AN, Harrison LH, Lyon GM, Arthington-Skaggs BA, Mirza $\mathrm{SA}$, et al. Incidence of bloodstream infections due to Candida species and in vitro susceptibilities of isolates collected from 1998 to 2000 in a population-based active surveillance program. J Clin Microbiol 2004; 42: 1519-1527.

18. Lyon GM, Karatela S, Sunay S, Adiri Y. Antifungal susceptibility testing of Candida isolates from the Candida surveillance study. J Clin Microbiol 2010; 48: 12701275 .

19. Oxman DA, Chow JK, Frendl G, Hadley S, Hershkovitz S, Ireland P, et al. Candidaemia associated with decreased in vitro fluconazole susceptibility: is Candida speciation predictive of the susceptibility pattern? J Antimicrobial Chem 2010; 65: 1460-1465.

20. Arendrup MC, Bruun B, Chritensen JJ, Fuursted K, Johansen HK, Kjaeldgaard P, et al. National Surveillance of Fungemia in Denmark (2004 to 2009). J Clin Microbiol 2011; 49: 325-334.

21. Bruder-Nascimento A, Camargo CH, Sugizaki MF, Sadatsune T, Montelli AC, Mondelli AL, et al. Species distribution and susceptibility profile of Candida species in a Brazilian public tertiary hospital. BCM Res Notes 2010; 3: 1-5.

22. Favalessa OC, Martins MA, Hahn RC. Mycological aspects and susceptibility in vitro the yeast of the genus Candida from HIV-positive patients in the State of Mato Grosso. Rev Soc Bras Med Trop 2010; 43: 673-677.

23. Li YL, Leaw SN, Chen J H, Chang HC, Chang TC. Rapid identification of yeasts commonly found in positive blood cultures by amplification of the internal transcribed spacer regions 1 and 2. Eur J Clin Microbiol Infet Dis 2003; 22: 693-696.

24. Williams JGK, Kubelik AR, Livak KJ, Rafalski JA, Tingey AV. DNA polymorphisms amplified by arbitrary primers are useful as genetic markers. Nucleic Acids Res 1990; 18: 6531-6535

25. Tavanti A, Davidson AD, Gow NAR, Maiden MCJ, Odds FC. Candida orthopsilosis and Candida metapsilosis spp. nov. to replace Candida parapsilosis groups II and III. J Clin Microbiol 2005; 43: 284-292.

26. Furlaneto-Maia L, Specian AF, Bizerra FC, Oliveira MT, Furlaneto MC. In vitro evaluation of putative virulence attributes of oral isolates of Candida spp. obtained from elderly healthy individuals. Mycopathologia 2008; 166: 209-217.

27. Khan ZU, Ahmad S, Mokaddas E, Chandy R. Tobacco Agar, a New Medium for Differentiating Candida dubliniensis from Candida albicans. J Clin Microbiol 2004; 42: 4796-4798.
28. The European Committee on Antimicrobial Susceptibility Testing Subcommittee on Antifungal Susceptibility Testing (EUCAST-AFST). EUCAST Technical Note on fluconazole. Clin Microbiol Infect 2008; 14: 193-195.

29. Ells R, Kock JLF, Pohl CH. Candida albicans or Candida dubliniensis? Mycoses 2009; 54: 1-16.

30. Hinrichsen SL, Falcão E, Vilella TAS, Rego L, Lira C, Almeida L, et al. Candida isolates in tertiary hospitals in northeastern Brazil. Braz J Microbiol 2009; 40: 325-328.

31. Bouza E, SanJaun R, Munoz P, Voss A, Kluytmans J. A European perspective on nosocomial urinary tract infections. I. Report on the microbiology workload, etiology and antimicrobial susceptibility (ESGNI-003 study). Clin Microbiol Infect 2001; 7: 523-531.

32. Shay AC, Miller LG An estimate of the incidence of candiduria among hospitilized patients in the United States. Infect Control Hosp Epidemiol 2004; 25: 894-895.

33. Passos XS, Sales WS, Maciel PJ, Costa CR, Miranda KC, Lemos JA, et al. Candida colonization in intensive care unit patients 'urine. Mem Inst Oswaldo Cruz 2005; 100: 925-928.

34. Silva EH, Ruiz LS, Matsumoto FE, Auler ME, Giudice MC, Moreira D, et al. Candiduria in a public hospital of São Paulo (1999-2004): characteristics of the yeast isolates. Rev Inst Med Trop São Paulo 2007; 49: 349-353.

35. Kauffman CA. Candiduria. Clin Infect Dis 2005; 41: S371-376.

36. Alvarez-Lerma F, Nolla-Salas J, Leon C, Palomas M, Jorda R, Carrasco N, et al. Candiduria in critically ill patients admittted to intensive care medical units. Intensive Care Med 2003; 29: 1069-1076.

37. Kobayashi CCBA, Fernandes OFL, Miranda KC, Sousa ED, Silva MRR. Candiduria in hospital patients: a study prospective. Mycopathologia 2004; 158: 49-52.

38. Binelli CA, Moretti ML, Assis RS, Sauaia N, Menezes PR, Ribeiro E, et al Investigation of the possible association betweeen nosocomial candiduria and candidemia. Clin Microbiol Infect 2006; 12: 538-543.

39. Figueiredo VT, Santos DA, Resende MA, Hamdan JS. Identification and in vitro antifungal susceptibility testing of 200 clinical isolates of Candida spp. responsible for fingernail infections. Mycopathologia 2007; 164:27-33.

40. Martins EA, Guerrer LV, Cunha KC, Soares MMCN, Almeida MTG. Onychomycosis: clinical, epidemiological and mycological study in the municipality of São José do Rio Preto. Rev Soc Bras Med Trop 2007; 40: 596-598.

41. Oliveira MT, Specian AFL, Andrade CGTJ, França EJG, Furlaneto-Maia L, Furlaneto MC. Interaction of Candida parapsilosis isolates with human hair and nail surfaces revealed by scanning electron microscopy analysis. Micron 2010; 41: 604-608.

42. Azoulay E, Timsit JF, Tafflet M, de Lassence A, Darmon M, Zahar JR, et al. Candida colonization of the respiratory tract and subsequent Pseudomonas ventilator-associated pneumonia. Chest 2006; 129: 110-117. 